\title{
Energy Consumption and Four Growth Hypotheses: An Evidence from SAARC Nations
}

\author{
Shafqut Ullah ${ }^{a}$, Tahir Mahmood ${ }^{\mathrm{b}}$ \\ ${ }^{a}$ Assistant Lecturer, Department of Economics, National University of Modern Languages, Islamabad, \\ Pakistan \\ Email: hshafqut@numl.edu.pk \\ ${ }^{\mathrm{b}}$ Assistant Professor, School of Economics, Quaid-i-Azam University, Islamabad ,Pakistan \\ Email: tahirraja20oo@yahoo.com
}

\begin{tabular}{l}
\hline ARTICLE DETAILS \\
\hline History: \\
Accepted o5 Dec 2020 \\
Available Online 31 Dec 2020
\end{tabular}

\section{Keywords:}

Growth Hypotheses, SAARC,

Panel Cointegration

\section{JEL Classification:}

$\mathrm{O} 47, \mathrm{C}_{33}$

DOI: $10.47067 /$ reads.v6i4.282

\begin{abstract}
The contemporaneous study investigates the directional relationship between economic growth and energy consumption for four selected $S A A R C$ nations from 1990 to 2018 within a panel-data framework. In the empirical literature, conservation, growth, feedback, and neutral hypotheses exist between energy and economic growth. First, study implies a Granger causality test to find the short-run directional relationship. Secondly, it checks the order of panel unit root that is a prerequisite condition for cointegration particularly when we have a long panel. In the end, based on panel unit root, the study estimates the model with the help of FMOLS to find a long-run relationship. The present study explores the conservation hypothesis in the short run at the regional level for Bangladesh and Pakistan. While the feedback hypothesis and neutral hypothesis exist in case of India and Sri-Lanka respectively. On the other hand, in the long run, there is cointegration between economic growth and energy use, while the direction conforms to the feedback hypothesis in our panel after allowing heterogeneous cross-sectional effect. Thus, energy and economic growth are coupled with each other in the long run at a regional level whereas, energy as a factor of the production process does not contribute significantly in the short run. It is because this region is labour abundant, therefore, the share of energy is significantly low in the final output as compared to developed nations. Consequently, the availability of energy at affordable prices truly matters for developing nations of SAARC.
\end{abstract}

(C) 2020 The authors. Published by SPCRD Global Publishing. This is an open access article under the Creative Commons Attribution-

NonCommercial 4.0

\section{Introduction}

Availability of energy at affordable prices is an important factor of the production process (Warr \& Ayres, 2010). There are substantial empirical evidences about healthy relationship 


\section{Review of Economics and Development Studies, Vol. 6 (4) 2020, 833 - 843}

between energy and economic growth (Al-mulali \& Binti Che Sab, 2012; Alam, Begum, Buysse, Rahman, \& Van Huylenbroeck, 2011; Alper \& Oguz, 2016; Bhattacharya, Paramati, Ozturk, \& Bhattacharya, 2016; Dogan, Sebri, \& Turkekul, 2016; Koçak \& Şarkgüneşi, 2017; Safdar, Asif, \& Farooq, 2020). This relationship is further categorized into four growth hypotheses and each hypothesis can be tested (Apergis \& Payne, 2009). The importance of energy consumption motivates this study to empirically estimate these hypotheses in case of selected South Asian Association for Regional Cooperation (SAARC) nations. This region is home to $23 \%$ of the World's population. From the last few decades, good economic performance of this region causes more energy consumption. In SAARC energy demand is growing with $5 \%$ growth rate while GDP per-capita growth rate is near to 5.2\% (ISGF, 2018). Consistent and balanced economic growth is a prerequisite condition for poverty reduction in this region. Almost the whole block depends upon imported energy in the form of oil. It acquires more consensus on the directional relationship between these two. Kraft \& Kraft, (1978) are the pioneers of the empirical work on energy and economic growth and then various studies try to find this directional relationship (Apergis \& Payne, 2009; Belloumi, 2009; Hondroyiannis, Lolos, \& Papapetrou, 2002; Huang, Hwang, \& Yang, 2008; Imran \& Siddiqi, 2010; C.-C. C. Lee, 2005; Masih \& Masih, 1996). However, there are discrepancies in empirical literature in form of causal relation between these two which convert it into a nexus. The literature about growth nexus is divided into steady state effects and transitional impacts. In the transitional phase, there is debate among the researchers regarding the direction of causality. There are four growth hypotheses in literature. The first one is conservation hypothesis and it is basically one-sided causality that runs from economic growth to energy consumption $(\mathrm{Y} \rightarrow \mathrm{EC})$. In simple words it is national income (economic growth) that causes more energy consumption (Mozumder \& Marathe, 2007). The second hypothesis is growth -hypothesis ( $\mathrm{Y} \leftarrow \mathrm{EC}$ ). Growth hypothesis means more energy consumption causes more economic growth. In this connection, the causal relationship is unidirectional but opposite in direction of conservation hypothesis. The third hypothesis is the feedback. It is bidirectional causal relationship that means energy use at national and economic growth cause each other ( $\mathrm{H} \leftrightarrow \mathrm{EC}$ ) (Belloumi, 2009). When there is no causality between these two it is called neutral hypothesis.

Present study contributes to existing literature in two unique ways: first, to our knowledge, it is foremost an attempt to empirically analyze the relationship between energy and economic growth in terms of four growth hypotheses for selected SAARC nations. Second, study also contributes to growth theory by introducing energy consumption into neoclassical growth theory along with capital and labor stocks, especially for SAARC nations.

The structure of study will covere the different aspects in the form of sections. In

following section 2 discuss the precise review of existing literature about energy-income nexus.. In section 3, describes the data and its source, model and different methods to estimate the model in the long and short run. Results and discussion along with some economic reasons are present in section 4 . At the end, section 5 concludes this study and suggests some possible policy recommendations.

\section{Literature Review}

First time Kraft \& Kraft (1978) empirically finds conservation hypothesis in case of the United States. Then a stream of empirical attempts is taken in this regard. Like, Oh \& Lee, (2004) find neutral hypothesis in short run and conservation hypothesis in the long run in case study of Korea. Furthermore, the same hypothesis is also found by Paul \& Bhattacharya, (2004) for India by using time series data. Likewise, Lee, (2005) investigates the same causal relationship for eighteen Asian countries and finds conservation hypotheses in short run as well as in long run. In this connection, Lee \& Chang, (2008) re-investigates the same relationship for sixteen Asian nations and finds cointegration. 


\section{Review of Economics and Development Studies, Vol. 6 (4) 2020, 833 - 843}

Additionally, Khan \& Qayyum, (2007) investigate the impact of energy use on economic growth in selected countries of SAARC and find conservation hypothesis in this region. Likewise, Jamil \& Ahmad, (2011) analyze the impact of energy price and real GDP on energy consumption in case of Pakistan and also examine causality from GDP to energy consumption (conservation hypothesis). There are many other empirical attempts that support the conservative hypothesis (Huang et al., 2008; Kasman \& Duman, 2015; Narayan, Narayan, \& Popp, 2010; Shahbaz \& Feridun, 2012). Empirical literature also supports the growth hypothesis (Apergis \& Payne, 2009; Aslan, Apergis, \& Yildirim, 2014; Ouedraogo, 2013; Ozturk et al., 2010). There is positive and bidirectional and cointegration between energy consumption and output of cement industry India (Mandal \& Madheswaran, 2010). Similarly, some studies support the feedback hypothesis that means bidirectional causal relationship exists between growth-energy (Belke et al., 2011; Coers \& Sanders, 2013). Zhang et al., (2011) find feedback hypothesis at industrial level of Beijing province of China. The feedback hypothesis explores for Belgium (Dogan et al., 2016). Menegaki \& Tugcu, (2016) support the neutral hypothesis for a panel of forty two subSaharan states. Streimikiene \& Kasperowicz, (2016) find the growth hypothesis in panel data analysis of 38 renewable energy consumer states. At last, few researchers discuss neutral impact and argue in favor of the neutrality hypothesis (Kahsai et al., 2012; Śmiech \& Papież, 2014; Wolde-Rufael, 2009).

There are two types of growth theories in literature, endogenous and exogenous growth theory (Romer, 2018). Both theories try to explain factors of growth of the real World. Once their focus on the aggregate level of savings as well as technology. In this connection, the both schools totally ignore the importance of energy in the production process (C.-C. Lee \& Chang, 2008). However, after the oil crisis of the 7os, there is a healthy debate among economists about the value of energy. Because this oil shock harmed the growth process of oil imported nations. It was Stern, (1993) who introduced energy as an additional factor in production process. According to Stern, productivity of energy matters for growth rather than energy consumption. Additionally, energy augmented labor introduced as a factor of production by a physicist economist (Pokrovski, 2003). The economy wide output is determined by its labor force and available energy resources (Pokrovski, 2003). From literature; we can conclude that strength and directions of relationship between energy and economic growth vary over society and over period of time.

Overall, the literature of energy and economic growth shows some similar results by covering the time span of 19070-2014. Therefore, the possible reason for this kind of results can introduce some biases by adopting the same methodology. Therefore, this innovative work extended this debate by introducing new variables and new econometric models because these variables are important for SAARC nations.

\section{Data, Model and Method to Estimate Growth Hypotheses}

To check the impact of energy on economic growth, this study is using panel data of four selected countries over the period of 1990 to 2018. Unfortunately, the data of total labor force is started from 1990 to onward for each cross section. The annual data are obtained from the World Development indicators (WDI 2018) for Bangladesh, India, Pakistan and Sri Lanka. The following multivariate model is used for analysis purposes.

$$
Y_{i t}=\beta_{0}+\beta_{1} G F C_{i t}+\beta_{2} L F_{i t}+\beta_{3} E C_{i t}+\mu_{i t}
$$

Equation(1) states that energy consumption (EC), gross capital formation (GFC), and labor force (LF) are the main factors to derive GDP (Y) (Omri, 2013). Both Y and GFC are in constant 2010 U.S. Dollars. GFC is a proxy of capital stock (Apergis \& Payne, 2009). While EC is total energy consumption 


\section{Review of Economics and Development Studies, Vol. 6 (4) 2020, 833 - 843}

in ton oil equivalent (TOE). Evaluating the impacts of energy will help in redesigning the energy sector and introducing the new environmental strategies and policy tools. Energy production and energy consumption are playing a critical role to meet the environmental challenges. Usually, capital is categorised into physical and human capital. Governments play a key role in providing physical or public capital, like telecommunications and electricity. Therefore, the availability of physical capital affects the economic growth since it is assumed that public capital is an essential component of the production process. Additionally, the labor force is affecting growth positively in production. It means labor, capital, and energy consumption are considered critical inputs for the production process. We have long panel data sets, so the real issue of such type of data is heterogeneity.

\subsection{Unit Root}

First of all, we have to check the integrated level of all variables of our model that is a prerequisite for estimating the long run and short run relationships. we have to check the order of integration of each variable. For this purpose, in literature, many tests of panel unit root have been developed to check the order of integration. When we deal with long panel, generally it suffers from autocorrelation. According to Engle \& Granger, (1987), OLS provides spurious results in nature when estimating the model of non-stationary variables. On the same token, this spuriousness may also appear in the long-panel. In this study, we compute five different types of panel unit root tests Levin-Lin-Chu (LLC), Im, Pesaran and Shin (IPS), BU, Augmented Dickey Fuller (ADF) and Phillips Parron (PP) (Breitung, 2005; Im, Pesaran, \& Shin, 2003; Levin, Lin, \& Chu, 2002; Maddala \& Wu, 1999). Each test assumes that every cross section of panel follows the same unit root process except IPS. IPS treats each cross sectional as a separate entity and estimates separate regression for each cross section. The equation of IPS test is replication ADF test of time series data. However the following equation (2) is to be estimated for the IPS panel unit root (Apergis \& Payne, 2009).

$$
\Delta Z_{i t}=\alpha_{i}+\rho_{i} Z_{i t-1}+\sum_{j}^{k} Z_{i t-j}+v_{i t}
$$

Here, $\mathrm{i}$ and $\mathrm{t}$ represent cross section and time series. We test the null hypothesis is $\rho_{i}=\rho=0$ for all cross sections in case of LLC and UB unit root tests and the alternative hypothesis is $\rho<0$. On

the other hand, the null is $\rho_{i}=0$ against the alternative $\rho_{i}<0$ for each cross section in case of IPS, Fisher-ADF, and Fisher-PP tests (C.-C. C. Lee, 2005).

\subsection{Granger Causality}

Granger causality is a useful test for forecasting the dependent variable on the basis of available information of independent variable (Peng et al., 2016). According to Liu, (2018) the Granger causality test can be used to find the causal relationship in short run between two or more than two variables. Engle and Granger causality test for our panel as well as for each cross section is applied to check unidirectional and bidirectional relationship of energy and income. Let, we have total energy consumption and economic growth and both series are integrated at level I (1). It means both series are nonstationary at level but stationary at first difference. If the linear combination of two series is stationary at level I (o) then it implies there is cointegration (or long run relationship between two series). At least there would be one sided or unidirectional causal relationship between the two series (Engle \& Granger, 1987). If this causal relationship is just running from energy to economic growth, then it is a growth hypothesis. If this causal relationship is reversed, then it is a conservation hypothesis. If both cause each other then it is a feedback-hypothesis. 
Review of Economics and Development Studies, Vol. 6 (4) 2020, 833 - 843

\subsection{Cointegration Analysis}

$$
Y_{i t}=\lambda_{i}+\delta_{i} t+\beta_{i} Z_{i t}+V_{i t}
$$

Above equation (03) is heterogeneous panel cointegration and it allows different cross section effects (Pedroni, 2000). It is an extension of Engle Granger framework in panel setup (Liddle, 2012). There is "no cointegration" between $\boldsymbol{Y}_{\boldsymbol{i t}}$ and $\boldsymbol{Z}_{\boldsymbol{i t}}$ is null hypothesis of cointegration test. It means the predicted value of residual $\left(\widehat{V}_{i t}\right)$ is also non-stationary at level like $\boldsymbol{Y}_{\boldsymbol{i t}}$ and $\boldsymbol{Z}_{\boldsymbol{i} \boldsymbol{t}}$. If $\widehat{V}_{i t}$ is stationary at level, then there is cointegration or long run relationship between $\boldsymbol{Y}_{\boldsymbol{i} \boldsymbol{t}}$ and $\boldsymbol{Z}_{\boldsymbol{i} \boldsymbol{t}}$. In the above equation, $\lambda_{\boldsymbol{i}}$ and $\delta_{i}$ are parameters to capture cross-section fixed effects and deterministic trends of each cross section respectively. In other words, these parameters capture the heterogeneity among the cross sections and time specific heterogeneity (Apergis \& Payne, 2009; Pedroni, 2000).

\subsection{Fully Modified Ordinary Least Square}

After confirmation of the short run directional and long run deterministic relationship by Granger Causality and Pedroni tests, the next step is to find consistent and unbiased estimators of model. For this purpose, study uses the group mean panel Fully Modified Ordinary Least Square (FMOLS). This method was developed by Phillips and Hansen (1990). FMOLS is modified version of OLS that can asymptotically provide consistent, efficient (free from serial correlation) and free from endogeneity parameters of cointegration equation when we have non-stationary as well small data (Liddle, 2012; Pedroni, 2000; Ramirez, 2007).

\section{Results and Discussion}

\subsection{Panel Unit Root}

The following table 1 summarizes the results of five panel unit root tests that are discussed in the previous section. All tests fail to reject the null hypothesis of unit root at level with no time effects and with fixed time effects. However, all tests reject the null hypothesis of unit root at first difference. It implies that all variables are non-stationary at level. The basic framework LLC and UB test are the same while IPS, Fisher-ADF, and Fisher-PP follow different frameworks that allow cross section heterogeneity. While all tests treat each time series separately and allow heterogeneity then to combine the P-values for an overall test. If we apply conventional panel estimation techniques on such data (like pooled least square etc.) then outcomes will be inconsistent as well as biased. So, it is recommended whenever two or more series are no stationary then it is necessary to move towards the test of cointegration (Liu, 2018).

Table 1 Panel Unit Root

\begin{tabular}{|c|c|c|c|c|c|c|c|c|}
\hline \multirow[t]{2}{*}{ Level } & \multicolumn{4}{|c|}{ No time effects } & \multicolumn{4}{|c|}{ Fixed time effects } \\
\hline & GDP & EC & GFC & LF & GDP & EC & GFC & LF \\
\hline LLC & 6.31 & 3.69 & $3 \cdot 74$ & -1.03 & 2.53 & 0.19 & 1.34 & -3.74 \\
\hline UB & 8.51 & $4 \cdot 51$ & 4.03 & 1.64 & 1.88 & 2.78 & 0.55 & -0.85 \\
\hline IPS & 9.25 & 6.63 & 3.73 & 1.73 & 6.05 & $4 \cdot 31$ & -0.51 & 0.49 \\
\hline Fisher-ADF & $4 \cdot 96$ & 1.12 & 4.08 & 1.96 & 3.28 & 2.49 & 2.18 & 0.62 \\
\hline \multirow[t]{2}{*}{ Fisher-PP } & $5 \cdot 35$ & 0.77 & 4.76 & 0.20 & 3.71 & 2.33 & 2.83 & 1.34 \\
\hline & \multicolumn{4}{|c|}{ No time effects } & \multicolumn{4}{|c|}{ Fixed time effects } \\
\hline$\Delta \mathrm{LLC}$ & -1.41 & -6.01 & $-8.01^{*}$ & $-4.2^{* *}$ & $-6.06^{* *}$ & $-8.85^{*}$ & $-8.67^{*}$ & $-4.57^{*}$ \\
\hline$\Delta \mathrm{UB}$ & 0.96 & $-3 \cdot 74^{*}$ & $-2.67^{*}$ & $-2.62^{*}$ & -0.265 & $-3.53^{*}$ & $-4.04^{*}$ & $-1.79 * *$ \\
\hline$\Delta I P S$ & -0.99 & $-3.81^{*}$ & $-5.04^{*}$ & $-2.53^{*}$ & $-2.76 * *$ & $-5.16^{*}$ & $-4 \cdot 38^{*}$ & $-1.2^{* * *}$ \\
\hline$\Delta$ Fisher-ADF & $-5 \cdot 33^{*}$ & $-4.06^{*}$ & $-1.30 * * *$ & $-2.73^{*}$ & $-6.32^{*}$ & $-5.45^{*}$ & $-1.32 * * *$ & $-1.3^{* * *}$ \\
\hline$\Delta$ Fisher-PP & $-3.54^{*}$ & $-7.64^{*}$ & $-2.85^{*}$ & $-4 \cdot 34^{*}$ & $-6.319^{*}$ & $-9.16^{*}$ & $-3.17^{* *}$ & $-2.63^{*}$ \\
\hline
\end{tabular}

Notes: ${ }^{*},{ }^{*}$ and ${ }^{* * *}$ represents significance at the $1 \%, 5 \%$ and $10 \%$ levels, respectively. 


\subsection{Granger Causality}

It is necessary that series should be stationary to apply the Granger-Causality test for short run analysis. Therefore, we are using the first difference of all variables because at first difference they are stationary. In the following table 2, the results of Granger-Causality test for the overall panel and for each country are presented. At regional level, study finds unidirectional causality running from economic growth to energy consumption and it is classified as conservation hypothesis. The conservation hypothesis is a serious threat for environmental sustainability if this relation prevails in the long run. At cross sectional level, study finds conservation hypothesis in the case of Bangladesh and Pakistan. While in the case of India, there is a growth hypothesis at two percent level of significance, however, feedback hypothesis exists at $12 \%$ level of significance. In case of Sri Lanka, there is neutral hypothesis (see also: Lee \& Chiu, 2011). The main reason for neutral hypothesis in Sri-Lanka is terrorism activities in our selected time span.

Table 2 Granger Causlity Test

\begin{tabular}{|c|c|c|c|c|c|}
\hline $\begin{array}{c}\text { Dependent } \\
\text { variable }(\downarrow)\end{array}$ & GDP & EU & GFC & $\mathbf{L F}$ & Remarks \\
\hline GDP & & $0.66(0.52)$ & $1.05(0.35)$ & $0.77(0.47)$ & \multirow{4}{*}{$\begin{array}{c}\text { Conservation } \\
\text { Hypothesis }\end{array}$} \\
\hline EU & $2.46 *(0.08)$ & & $4.55^{* *}(0.012)$ & $0.38(0.68)$ & \\
\hline GFC & $0.31(0.73)$ & $1.27(0.28)$ & & $\begin{array}{c}17 \cdot 32^{* *} \\
(0.00)\end{array}$ & \\
\hline LF & $0.27(0.76)$ & $0.24(0.79)$ & $0.50(0.61)$ & & \\
\hline \multicolumn{5}{|c|}{ Bangladesh } & \multirow{3}{*}{$\begin{array}{c}\text { Conservation } \\
\text { Hypothesis }\end{array}$} \\
\hline GDP & & $0.23(0.80)$ & & & \\
\hline EU & $6.33^{* *}(0.005)$ & & & & \\
\hline \multicolumn{5}{|c|}{ India } & \multirow{3}{*}{$\begin{array}{c}\text { Feedback } \\
\text { Hypothesis at } \\
12 \% \\
\end{array}$} \\
\hline GDP & & $4.47^{* *}(0.021)$ & & & \\
\hline EU & $2.30 * * *(0.12)$ & & & & \\
\hline \multicolumn{5}{|c|}{ Pakistan } & \multirow{3}{*}{$\begin{array}{c}\text { Conservation } \\
\text { Hypothesis }\end{array}$} \\
\hline GDP & & $1.05(0.37)$ & & & \\
\hline EU & $3.62 *(0.039)$ & & & & \\
\hline \multicolumn{5}{|c|}{ Sri Lanka } & \multirow{3}{*}{$\begin{array}{c}\text { Neutral } \\
\text { Hypothesis }\end{array}$} \\
\hline GDP & & $1.22(0.32)$ & & & \\
\hline EU & $0.81(0.46)$ & & & & \\
\hline
\end{tabular}

Notes: * ** and ${ }^{* * *}$ represent significance at the 5\%, 10\% and $12 \%$ levels, respectively.

\subsection{Panel Cointegration Test}

To examine the long run relationship or cointegration, present study employs the Pedroni cointegration test (Pedroni, 2000). The results of the Pedroni test have three columns. The second column is labeled with panel statistics that further four test values. In panel statistics, it is assumed that autoregressive term AR (1) is identical across the cross sections. This first-order autoregressive term can be varying in case of group statistics. If the null hypothesis is rejected, then it implies that variables are cointegrated for all cross sections. On the same token, if the null hypothesis is rejected in case of group statistics then it implies that there is cointegration among variables at least in case of one cross section. The PP and ADF statistics confirm the cointegration in the panel. The null hypothesis is rejected in both cases at five percent level of significance. It means there is a long run relationship between energy consumption and economic growth in panel as well as in each cross section. 
Review of Economics and Development Studies, Vol. 6 (4) 2020, 833 - 843

Table 3 Cointegration Test

\begin{tabular}{|c|c|c|c|}
\hline & Panel statistics & Weighted statistics & Group Statistics \\
\hline Variance Ratio & $-0.06(0.52)$ & $0.57(0.28)$ & ----- \\
\hline Rho statistic & $0.15(0.55)$ & $-0.48(0.32)$ & $0.39(0.65)$ \\
\hline PP Statistics & $-1.87^{*}(0.03)$ & $-2.17^{*}(0.02)$ & $-1.90^{*}(0.029)$ \\
\hline ADF Statistics & $-1.88^{*}(0.03)$ & $-2.31^{*}(0.01)$ & $-1.58^{*}(0.057)$ \\
\hline
\end{tabular}

\subsection{Fully Modified Ordinary Least Square (FMOLS)}

For long run, we estimate two separate equations with the help of FMOLS. In following table 4 the long run coefficients along with t-values for each estimated equation are presented. There is significant role of energy use, capital stock and labor in shaping the growth path of SAARC region. This situation also confirms the neoclassical or exogenous growth theory. Energy as a factor of production plays a significant role to achieve goal of economic convergence. On the other hand, the second equation confirms that economic growth, capital stock and labor force have also statistically significant impact on regional level energy use. It is implying that there is feedback hypothesis exist. Moreover, capital stock causes more energy consumption in the long run that further deteriorate the regional environmental situation. Our long run results confirm the feedback hypothesis. It means the promotion of energy consumption policies are effective in terms of economic growth, which in reward further expands the energy demand through dynamic process in the long run.

Table 4 FMOLS

\begin{tabular}{|c|c|c|c|c|c|c|c|r|}
\hline GDP & EC & t-value & GDP & t-value & GFC & t- value & LFT & t-value \\
\hline & $\begin{array}{c}5.02 \\
*\end{array}$ & 2.79 & & & $151.36^{*}$ & 4.21 & $0.017^{*}$ & 3.68 \\
\hline EC & & & $\begin{array}{c}0.02 \\
7\end{array}$ & 2.21 & 36.56 & 2.61 & 0.001 & 2.85 \\
\hline
\end{tabular}

Gross fix capital (GFC) and Labor force (FT) are in natural log form. *indicates coefficients are significance at the $1 \%$ level.

\section{Conclusion and Policy Recommendations}

Analyzing the income-energy nexus is necessary for effective energy and environment related policies. After the 7os oil shock researchers realized the importance of energy and a stream of research endeavored to investigate this nexus. However, the present study tries to investigate this relationship in form of four growth hypotheses (conservation, feedback, growth, and neutral hypothesis). For this analysis, study selects Pakistan, India, Bangladesh, and Sri-Lanka from the SAARC region. In the panel, there are four developing economies and data are collected from WDI from 1990 to 2018. First, the study checks the unit root level of each variable as it is a prerequisite for panel dynamic analysis. Then for short run analysis, the study used the Granger causality test and finds conservation hypothesis for the panel. The same hypothesis exists in the case of Bangladesh and Pakistan and feedback hypothesis for India. Neutral hypothesis holds in case of Sri Lanka. The short run results reveal a variation across the cross sections in terms of energy-income. The study finds a balanced state relationship between energy consumption and economic growth in this region by using the heterogeneous panel cointegration technique. Moreover, to check the cointegration in panel, the study has used Pedroni cointegration test and found the feedback hypothesis in our panel the long run. Therefore, energy and economic growth have strong relationship in the long run. This effective relation boosts the demand for labor and increases the productivity of labor and capital of this region. The intra-regional energy trade 


\section{Review of Economics and Development Studies, Vol. 6 (4) 2020, 833 - 843}

is about five percent of total regional trade among the SAARC nations. However, there are several hidden opportunities for member states to promote regional energy trade and cooperation for better future of this region and humanity. In the following years, the expected rate of economic growth will be increased in SAARC region leading to serious concerns related to sustainability of environment. Therefore, active energy conservation policies should be opted at regional level as well as at national level. To achieve the unique goal of sustainability, there should be regional cooperation among SAARC members.

\section{References}

Al-mulali, U., \& Binti Che Sab, C. N. (2012). The impact of energy consumption and CO2 emission on the economic and financial development in 19 selected countries. Renewable and $\begin{array}{llll}\text { Sustainable } \quad \text { Energy } & \text { Reviews, } & \text { 4365-4369. }\end{array}$ https://doi.org/10.1016/J.RSER.2012.05.017

Alam, M. J., Begum, I. A., Buysse, J., Rahman, S., \& Van Huylenbroeck, G. (2011). Dynamic modeling of causal relationship between energy consumption, $\mathrm{CO} 2$ emissions and economic growth in India. Renewable and Sustainable Energy Reviews, 15(6), 3243-3251. https://doi.org/10.1016/J.RSER.2011.04.029

Alper, A., \& Oguz, O. (2016). The role of renewable energy consumption in economic growth: Evidence from asymmetric causality. Renewable and Sustainable Energy Reviews, 60, 953959. https://doi.org/10.1016/J.RSER.2016.01.123

Apergis, N., \& Payne, J. E. (2009). Energy consumption and economic growth: Evidence from the Commonwealth of Independent States. Energy Economics, 31(5), 641-647. https://doi.org/10.1016/j.eneco.2009.01.011

Aslan, A., Apergis, N., \& Yildirim, S. (2014). Causality between energy consumption and GDP in the U.S.: evidence from wavelet analysis. Frontiers in Energy, 8(1), 1-8. https://doi.org/10.1007/s11708-013-0290-6

Belke, A., Dobnik, F., \& Dreger, C. (2011). Energy consumption and economic growth: New insights into the cointegration relationship. Energy Economics, 33(5), 782-789. https://doi.org/10.1016/J.ENECO.2011.02.005

Belloumi, M. (2009). Energy consumption and GDP in Tunisia: Cointegration and causality analysis. Energy Policy, 37(7), 2745-2753. https://doi.org/10.1016/J.ENPOL.2009.03.027

Bhattacharya, M., Paramati, S. R., Ozturk, I., \& Bhattacharya, S. (2016). The effect of renewable energy consumption on economic growth: Evidence from top 38 countries. Applied Energy, 162, 733-741. https://doi.org/10.1016/J.APENERGY.2015.10.104

Breitung, J. (2005). The local power of some unit root tests for panel data. Humboldt-Universität zu Berlin, Wirtschaftswissenschaftliche Fakultät.

Coers, R., \& Sanders, M. (2013). The energy-GDP nexus; addressing an old question with new methods. $\quad$ Energy $\quad$ Economics, $36, \quad 708-715$. https://doi.org/https://doi.org/10.1016/j.eneco.2012.11.015

Dogan, E., Sebri, M., \& Turkekul, B. (2016). Exploring the relationship between agricultural electricity consumption and output: New evidence from Turkish regional data. Energy Policy, 95, 370-377. https://doi.org/https://doi.org/10.1016/j.enpol.2016.05.018

Engle, R. F., \& Granger, C. W. J. (1987). Co-integration and error correction: representation, estimation, and testing. Econometrica: Journal of the Econometric Society, 55, 251-276.

Hondroyiannis, G., Lolos, S., \& Papapetrou, E. (2002). Energy consumption and economic growth: Assessing the evidence from Greece. Energy Economics, 24(4), 319-336. https://doi.org/10.1016/So140-9883(02)0ooo6-3

Huang, B.-N., Hwang, M. J., \& Yang, C. W. (2008). Causal relationship between energy 


\section{Review of Economics and Development Studies, Vol. 6 (4) 2020, 833 - 843}

consumption and GDP growth revisited: A dynamic panel data approach. Ecological Economics, 67(1), 41-54. https://doi.org/https://doi.org/10.1016/j.ecolecon.2007.11.006

Im, K. S., Pesaran, M. H., \& Shin, Y. (2003). Testing for unit roots in heterogeneous panels. Journal of Econometrics, 115(1), 53-74.

Imran, K., \& Siddiqi, D. M. (2010). Energy Consumption and Economic Growth: A Case Study of Three SAARC Countries. European Journal of Social Sciences, 16, 206-213. https://doi.org/10.2139/ssrn.2124639

ISGF. (2018). Study on Infrastructure and Enabling Environment for Road Electric Transport in SAARC Member States.

Jamil, F., \& Ahmad, E. (2011). Income and price elasticities of electricity demand: Aggregate and $\begin{array}{llll}\text { sector-wise } \quad \text { analyses. } & \text { Energy } & \text { 50licy, }\end{array}$ https://doi.org/10.1016/j.enpol.2011.05.010

Kahsai, M. S., Nondo, C., Schaeffer, P. V, \& Gebremedhin, T. G. (2012). Income level and the energy consumption-GDP nexus: Evidence from Sub-Saharan Africa. Energy Economics, 34(3), 739-746. https://doi.org/https://doi.org/10.1016/j.eneco.2011.06.0o6

Kasman, A., \& Duman, Y. S. (2015). CO2 emissions, economic growth, energy consumption, trade and urbanization in new EU member and candidate countries: A panel data analysis. Economic Modelling, 44, 97-103. https://doi.org/https://doi.org/10.1016/j.econmod.2014.10.022

Khan, M. A. ;, \& Qayyum, A. (2007). Dynamic Modelling of Energy and Growth in South Asia. The Pakistan Development Review, 46(4), 481-498. Retrieved from http://www.pide.org.pk/pdf/PDR/2007/Volume4/481-498.pdf

Koçak, E., \& Şarkgüneşi, A. (2017). The renewable energy and economic growth nexus in Black Sea and Balkan countries. Energy Policy, 100, 51-57. https://doi.org/https://doi.org/10.1016/j.enpol.2016.10.007

Kraft, J., \& Kraft, A. (1978). On the relationship between energy and GNP. Journal of Energy and Development, 401-403., 3, 401-403.

Lee, C.-C. C. (2005). Energy consumption and GDP in developing countries: A cointegrated panel analysis. Energy Economics, 27(3), 415-427. https://doi.org/10.1016/J.ENEC0.2005.03.003

Lee, C.-C., \& Chang, C.-P. (2008). Energy consumption and economic growth in Asian economies: A more comprehensive analysis using panel data. Resource and Energy Economics, 30(1), 50-65. https://doi.org/10.1016/J.RESENEEC0.2007.03.003

Lee, C.-C., \& Chiu, Y.-B. (2011). Nuclear energy consumption, oil prices, and economic growth: Evidence from highly industrialized countries. Energy Economics, 33(2), 236-248.

Levin, A., Lin, C.-F. F., \& Chu, C.-S. S. J. (2002). Unit root tests in panel data: asymptotic and finite-sample properties. Journal of Econometrics, 108(1), 1-24. https://doi.org/10.1016/So304-4076(01)ooo98-7

Liddle, B. (2012). The importance of energy quality in energy intensive manufacturing: Evidence from panel cointegration and panel FMOLS. Energy Economics, 34(6), 1819-1825. https://doi.org/10.1016/j.eneco.2012.07.013

Liu, X. (2018). Aggregate and disaggregate analysis on energy consumption and economic growth nexus in China. Environmental Science and Pollution Research, 25(26), 26512-26526. https://doi.org/10.1007/s11356-018-2699-2

Maddala, G. S., \& Wu, S. (1999). A comparative study of unit root tests with panel data and a new simple test. Oxford Bulletin of Economics and Statistics, 61(S1), 631-652.

Mandal, S. K., \& Madheswaran, S. (2010). Causality between energy consumption and output growth in the Indian cement industry: An application of the panel vector error correction model (VECM). Energy Policy, 38(11), 6560-6565. 


\section{Review of Economics and Development Studies, Vol. 6 (4) 2020, 833 - 843}

Masih, A. M. M., \& Masih, R. (1996). Energy consumption, real income and temporal causality: results from a multi-country study based on cointegration and error-correction modelling techniques. Energy Economics, 18(3), 165-183. https://doi.org/10.1016/01409883(96)oooog-6

Menegaki, A. N., \& Tugcu, C. T. (2016). Rethinking the energy-growth nexus: Proposing an index of sustainable economic welfare for Sub-Saharan Africa. Energy Research \& Social Science, 17, 147-159. https://doi.org/https://doi.org/10.1016/j.erss.2016.04.009

Mozumder, P., \& Marathe, A. (2007). Causality relationship between electricity consumption and GDP in Bangladesh. Energy Policy, 35(1), 395-402. https://doi.org/10.1016/J.ENPOL.2005.11.033

Narayan, P. K., Narayan, S., \& Popp, S. (2010). A note on the long-run elasticities from the energy consumption-GDP relationship. Applied Energy, 87(3), 1054-1057. https://doi.org/https://doi.org/10.1016/j.apenergy.2009.08.037

Oh, W., \& Lee, K. (2004). Energy consumption and economic growth in Korea: testing the causality relation. Journal of Policy Modeling, 26(8-9), 973-981. https://doi.org/10.1016/J.JPOLMOD.2004.06.003

Omri, A. (2013). CO2 emissions, energy consumption and economic growth nexus in MENA countries: Evidence from simultaneous equations models. Energy Economics, 40, 657-664. https://doi.org/10.1016/j.eneco.2013.09.003

Ouedraogo, N. S. (2013). Energy consumption and economic growth: Evidence from the economic community of West African States (ECOWAS). Energy Economics, 36, 637-647. https://doi.org/https://doi.org/10.1016/j.eneco.2012.11.011

Ozturk, I., Aslan, A., \& Kalyoncu, H. (2010). Energy consumption and economic growth relationship: Evidence from panel data for low and middle income countries. Energy Policy, 38(8), 4422-4428. https://doi.org/https://doi.org/10.1016/j.enpol.2010.03.071

Paul, S., \& Bhattacharya, R. N. (2004). Causality between energy consumption and economic growth in India: a note on conflicting results. Energy Economics, 26(6), 977-983. https://doi.org/10.1016/J.ENECO.2004.07.002

Pedroni, P. (2000). Fully modified OLS for heterogeneous cointegrated panels. Advances in Econometrics, 15, 93-130.

Peng, H., Tan, X., Li, Y., \& Hu, L. (2016). Economic growth, foreign direct investment and CO2 emissions in China: A panel granger causality analysis. Sustainability (Switzerland), 8(3). https://doi.org/10.3390/su8030233

Pokrovski, V. N. (2003). Energy in the theory of production. Energy, 28(8), 769-788.

Ramirez, M. D. (2007). A panel unit root and panel cointegration test of the complementarity hypothesis in the Mexican case: 1960-2001. Atlantic Economic Journal, 35(3), 343-356.

Romer, D. (2018). Macroeconomic theory. UNIVERSITY OF CALIFORNIA, Berkeley.

Safdar, N., Asif, H., \& Farooq, F. (2020). Energy Use and Human Health Nexus in Pakistan. Review of Economics and Development Studies, 6(3), 661-674.

Shahbaz, M., \& Feridun, M. (2012). Electricity consumption and economic growth empirical evidence from Pakistan. Quality and Quantity, 46(5), 1583-1599. https://doi.org/10.1007/s11135-011-9468-3

Śmiech, S., \& Papież, M. (2014). Energy consumption and economic growth in the light of meeting the targets of energy policy in the EU: The bootstrap panel Granger causality approach. Energy Policy, 71, 118-129. https://doi.org/https://doi.org/10.1016/j.enpol.2014.04.005

Stern, D. I. (1993). Energy and economic growth in the USA. A multivariate approach. Energy Economics, 15(2), 137-150. https://doi.org/10.1016/0140-9883(93)90033-N

Streimikiene, D., \& Kasperowicz, R. (2016). Review of economic growth and energy consumption: 
A panel cointegration analysis for EU countries. Renewable and Sustainable Energy Reviews, 59, 1545-1549. https://doi.org/10.1016/j.rser.2016.01.041

Warr, B. S., \& Ayres, R. U. (2010). Evidence of causality between the quantity and quality of energy consumption and economic growth. Energy, 35(4), 1688-1693. https://doi.org/https://doi.org/10.1016/j.energy.2009.12.017

Wolde-Rufael, Y. (2009). Energy consumption and economic growth: The experience of African countries revisited. Energy Economics, 31(2), 217-224. https://doi.org/https://doi.org/10.1016/j.eneco.2008.11.005

World Development Indicators (WDI). (2018).

Zhang, X., Wang, C., Tan, Y., \& Zhang, F. (2011). Causality between energy consumption and economic growth in Beijing: Evidence from cross-industry panel data. In Communications in Computer and Information Science (Vol. 217 CCIS, pp. 233-237). Springer, Berlin, Heidelberg. https://doi.org/10.1007/978-3-642-23339-5_42 